\title{
Structure of conceptual models in the senior operating staff of nuclear power plants
}

\author{
Aleksandr A. Oboznov ${ }^{\mathrm{a}^{*}}$, Elena D. Chernetskaya ${ }^{\mathrm{b}}$, Yulia V. Bessonova ${ }^{\mathrm{a}}$ \\ a Institute of Psychology, the Russian Academy of Sciences, Moscow, Russia \\ b "ROSATOM - CICE\&T" \\ *Corresponding author. E-mail: aao46@mail.ru
}

Background. The relationships between conceptual model structures and an operator's professional efficiency are of direct practical importance, particularly in the case of large-scale industrial complexes combining several human-machine systems. A typical example is the power unit of a nuclear power plant (NPP).

Objective and Methods. The purpose of this study was to explore the conceptual models of senior reactor operators (SROs) of NPPs. The study involved 64 men working as SRO at five NPPs in Russia. The methods included: structured interviews, expert estimations, multidimensional scaling (ALSCAL), the K-means clustering algorithm, and frequency analysis. The procedure was as follows: 32 key characteristics of the power unit were defined, including shift operators' jobs and duties, technical subsystems, types of equipment, and the crucial power unit parameters. The participants were offered a $32 \times 32$ matrix for pair-wise estimation of the strength of the links between these key characteristics on a seven-point scale (496 links in total).

Results. A general scheme of key characteristics in the conceptual models was defined. This scheme was displayed in the operators regardless of their employment history. Within the scheme, however, two types of conceptual models were identified, which could be distinguished by the relative number of strong links between the key characteristics. With respect to intersystem links including key characteristics of the reactor and turbine NPP departments, this number was significantly higher in models of Type 1 than in those of Type 2. A positive correlation between the number of these links and the professional efficiency indicators was also established. Operators with Type 1 models were able to more predictably represent the power unit operation.

Conclusion. The main role in creating predictable and efficient conceptual models was played by strong intersystem links in mental representations of workflow.

Keywords: Nuclear Power Plant (NPP) senior reactor operator (SRO), conceptual model, mental image, multidimensional scaling, workflow, subjective strength of links, professional efficiency 


\section{Introduction}

L.S. Vygotsky (1982) stated that the development of mind causes changes not so much in existing mental functions, as in the links between them, resulting in the emergence of new psychological systems. This observation is fully applicable to the development of new cognitive structures necessary to regulate professional activity. One of these is the "conceptual model" used by human operators in their work. The notion was introduced into human-factor engineering and psychology by A.T. Welford (1961) as a workflow "mental image" necessary for the operator to control the process. This model, although inexact, allows the operator to correlate different workflow stages, and to act proactively and efficiently. In the Russian literature, this notion has become quite widespread (Zinchenko, 1970; Lomov, 1977; Galaktionov, 1992; Oboznov, 2009; Oboznov et al., 2013a; Bessonova, 2012; Ryabov, 2014; Chernetskaya, 2014). In fact, it is similar to one of the basic concepts of Russian psychology, the "operative image" (Oshanin, 1969).

A study of conceptual models proceeds from a scientific description of their functions to the identification of their content and structures. The content consists of the operator's views and knowledge of the human - machine system (HMS) workflows, working environment, typical problem situations, decision-making rules, operator's tasks and methods, programs of control (Munipov, \& Zinchenko, 2001), as well as the required workflow dynamics (Oshanin, 1977). The content of a conceptual model also includes knowledge gained in professional experience. Of course, the representations of knowledge in a conceptual model has to be organized in a certain way, a structure. The reason that cognitive science is interested in mental structures is to better understand how the acquisition, memorization, transfer, and use of new information depends on the ways that pre-existing knowledge is organized (Anderson, 2002; Velichkovsky, 2006).

This also applies to the HMS operators' conceptual model structures. The results of a few empirical studies have shown that, for skilled operators, the structures of conceptual models differ little from one another; at the same time, they differ greatly from the ways that novices in the profession organize workflow-related knowledge (Cooke, \& McDonald, 1987; Golikov, 2003). The relationships between conceptual model structures and an operator's professional efficiency are of direct practical importance, particularly in large-scale industrial complexes combining several HMSs. A typical example is the power unit of a nuclear power plant (NPP). The power unit includes two HMSs, a reactor department and a turbine department, which, in turn, include a number of subsystems. To understand the power unit operation, predict trends, and make decisions, especially in abnormal situations, the conceptual model of senior reactor operators (SROs) should represent both the intrasystem links among the characteristics of the reactor department and the intersystem links among the characteristics of the reactor and turbine departments. The difference between these types of links is that the intrasystem links, due to their limited mutual influences, are more predictable, while the intersystem links are much less predictable due to the complexity of their direct and indirect interaction (Golikov, \& Costin, 1999). This creates an additional hazard potential of such HMS complexes for society and the environment. The present study was carried out on a large group of SROs to identify their types of conceptual models and, in particular, the relationships between the structure of those conceptual models and the operators' professional efficiency. 


\section{Method}

\section{Participants}

The study involved 64 men working as SROs at five Russian NPPs. Their length of service ranged from 6 months to 34 years.

\section{Procedure}

The study included four stages. At the first stage, two experts (NPP operators with high professional qualification and over 10 years of work experience) specified a list of key characteristics of a power unit to be contained in the SRO conceptual models. At the second stage, the participants gave a subjective assessment of the strength of links between the key characteristics of the power unit. At the third stage, a general scheme of the SROs' conceptual model structures and their types was defined. At the fourth and final stage, the SROs' professional efficiency was evaluated and its relationship with the type of conceptual model was determined.

Structured interviews were used to identify the key characteristics of the power unit to be contained in the SRO conceptual models. To estimate the strength of links between the key characteristics, participants were provided with a $32 \times 32$ matrix for pair-wise comparison of the indicated characteristics. The strength of links between all the key characteristics (496 in total) was estimated on a sevenpoint scale: $7=$ very strong; $6=$ strong; $5=$ above average; $4=$ average; $3=$ below average; 2 =weak; 1 =very weak. Further, these links were analyzed in three aspects. In the first, the links were considered by the criterion of their subjective strength for the SROs, namely, as strong, average, or weak. In the second aspect, these links were considered by the criterion of their affiliation, that is, as intrasystem ones, linking the key characteristics only to the "Reactor Department" HMS or the "Turbine Department" HMS, and intersystem ones, linking the key characteristics of both HMSs. In the third aspect, the same links were considered by the criterion of their function in the SRO's professional activity. The following links were analyzed:

- links that perform a cognitive function and reflect the operation of the power unit as a technical complex without the operator's direct intervention (power unit operation links), that is, among the technical subsystems, equipment, aggregates and their parameters; a set of SRO representations of these links is the cognitive component of the conceptual model;

- links that perform a regulatory function, i.e., between the operators' duties and the controlled technical subsystems, units of equipment, aggregates and their parameters (power unit control links); these links reflect the zones of each operator's personal responsibility for the management and control of a certain power unit section; a set of SRO representations of these links is the regulatory component of the conceptual model;

- links that perform a communicative function, i.e., between the duty shift operators' jobs and duties (operator communication links); these links reflect the power unit operators' interactions; a set of SRO representations of these links is the communicative component of the conceptual model. 
To define a general structural scheme of the conceptual models, a $32 \times 32$ matrix was used, averaged over the entire group of 64 participants. This matrix underwent multidimensional scaling (ALSCAL), followed by the construction of a twodimensional semantic space. The conceptual model structural types were identified using the K-means clustering algorithm.

Finally and in order to determine the SRO's professional efficiency, the expert estimation method was used. Expert estimations were made on a 9-point scale by a group of three experts: the immediate supervisor of the operator being evaluated, a training center instructor, and a full-time psychologist engaged in emergency training of operators on a full-scale power unit simulator. The consistency of expert estimations was determined using Kendall's coefficient of concordance (W).

\section{Results}

The structured interview with two experts revealed four classes of key characteristics of power units, which should be contained in the SRO conceptual models:

- shift operators' jobs (NPP shift supervisor, power unit shift supervisor, operator-inspectors, etc.);

- shift operators' duties (operational personnel management, operational control of the primary circuit parameters, etc.);

- power unit technical subsystems and equipment (vacuum system, main circulation pump, turbine generator, etc.);

- parameters of power unit technical subsystems and equipment (power reactivity margin, electrical capacity, etc.).

In total, for further research, the experts selected 32 key characteristics ( 8 characteristics of each type).

The data presented in Table 1 shows how the SRO's understanding of the strength of links depended on the function of these links in professional activity.

According to the reports, strong and very strong (6-7 points) power unit operation links (cognitive function) meant that, when one key characteristic changes, another key characteristic will always (or almost always) change too. In fact, a strong link was understood by the operators as a cause-and-effect relationship. The average (3-5 points) power unit operation links meant that, if the condition of one technical subsystem (parameter) changes, the condition of another technical subsystem (parameter) might or might not change with equal probability. The weak (1-2 points) power unit operation links meant that, that, if the condition of one technical subsystem (parameter) changes, the condition of another technical subsystem (parameter) changes very rarely, if ever.

The strong and very strong (6-7 points) power unit control links (regulatory function) meant that the SRO official duties are related to their personal responsibility for the management and control of particular technical subsystems, aggregates and their parameters. The average (3-5 points) power unit control links meant that the SRO's official duties are related to their indirect responsibility for the management and control of particular technical subsystems, aggregates and their 
Table 1. SRO understanding of the strength of links between key characteristics of the power unit

Functions

SRO understanding of the strength of links between

the key characteristics of the power unit

\begin{abstract}
Cognitive (power Strong and very strong (6-7 points): when one characteristic changes, it will
unit

operation links)

(almost) always cause a change in another characteristic (cause-and-effect

relationship).

Average (3-5 points): when one characteristic changes, another one might or might not change, with approximately equal probability.

Weak and very weak (1-2 points): when one characteristic changes, another characteristic changes very rarely, if ever.
\end{abstract}

Regulatory Strong and very strong (6-7 points): the operator bears personal (direct) re(power unit con- sponsibility for the management and control of a particular type of equiptrol links) ment or its parameter.

Average (3-5 points): the operator bears indirect responsibility for the management and control of a particular type of equipment or its parameter.

Weak and very weak (1-2 points): the operator bears no responsibility for the management and control of a particular type of equipment or its parameter.

Communicative Strong and very strong (6-7 points): joint involvement in activities occurs (operator communication links) (almost) always.

Average (3-5 points): joint involvement in activities occurs or does not occur with equal probability.

Weak and very weak (1-2 points): joint involvement in activities occurs very rarely, if ever.

parameters, which were not areas of the SRO's personal responsibility, but could be indirectly influenced by their actions. The weak (1-2 points) power unit control links meant that operators' official duties were unrelated to the management and control of particular technical subsystems and their parameters.

The strong and very strong (6-7 points) operator communication links (communicative function) meant that one operator could perform his official duties only if another operator did so. The average (3-5 points) operator communication links meant that the dependence of one operator's performing his official duties on another operator's doing so might or might not be manifested, according to the circumstances. The weak (1-2 points) operator communication links meant that one operator's performing his official duties did not depend on another operator's doing so.

The common point in the SROs' understanding of the strength of all the considered links is as follows: the stronger these links, the more predictable the mutual influences of the key characteristics being linked. At the same time, the relative number of strong links was significantly different in the cognitive, regulatory, and communicative components of the conceptual model (see Table 2).

The data presented in Table 2 suggest that the power unit operation links (cognitive component) were estimated by the senior reactor operators mostly as weak. Generally speaking, this representation adequately reflects the NPP power unit operation as a human-machine complex which has numerous intra- and intersystem links, including non-linear and unstable interactions, unstable and extreme work- 
Table 2. Distribution (\%) of links of different strengths in the conceptual model components (data averaged over the total group of 64 senior reactor operators)

\begin{tabular}{lcccc}
\hline \multirow{2}{*}{ Components } & \multicolumn{3}{c}{ Strength of links } & Total \\
\cline { 2 - 4 } & Weak & Average & Strong & $(\%)$ \\
\hline $\begin{array}{l}\text { Cognitive component } \\
\text { (power unit operation links) }\end{array}$ & 48.0 & 24.0 & 28.0 & 100.0 \\
$\begin{array}{l}\text { Regulatory component } \\
\text { (power unit control links) }\end{array}$ & 32.0 & 26.5 & 41.5 & 100.0 \\
$\begin{array}{l}\text { Communicative component } \\
\text { (operator communication links) }\end{array}$ & 22.5 & 19.5 & 58.0 & 100.0 \\
\hline
\end{tabular}

ing conditions, the influence of subjective factors associated with the operational personnel control input, etc. (Anokhin, \& Ostreykovsky, 2001). A different picture was observed in the power unit control links (regulatory component). These links were estimated by the operators as strong in $41.5 \%$ of cases, or 1.5 times more often than in the power unit operation links. The operator communication links (communicative component) were estimated as strong even more often, in 58\% of cases. This means that for the SROs, the most predictable were the links reflecting the duty shift operators' interactions.

As a result of applying multidimensional scaling to the $32 \times 32$ matrix averaged for all 64 participants, a generalized semantic space of the conceptual model was
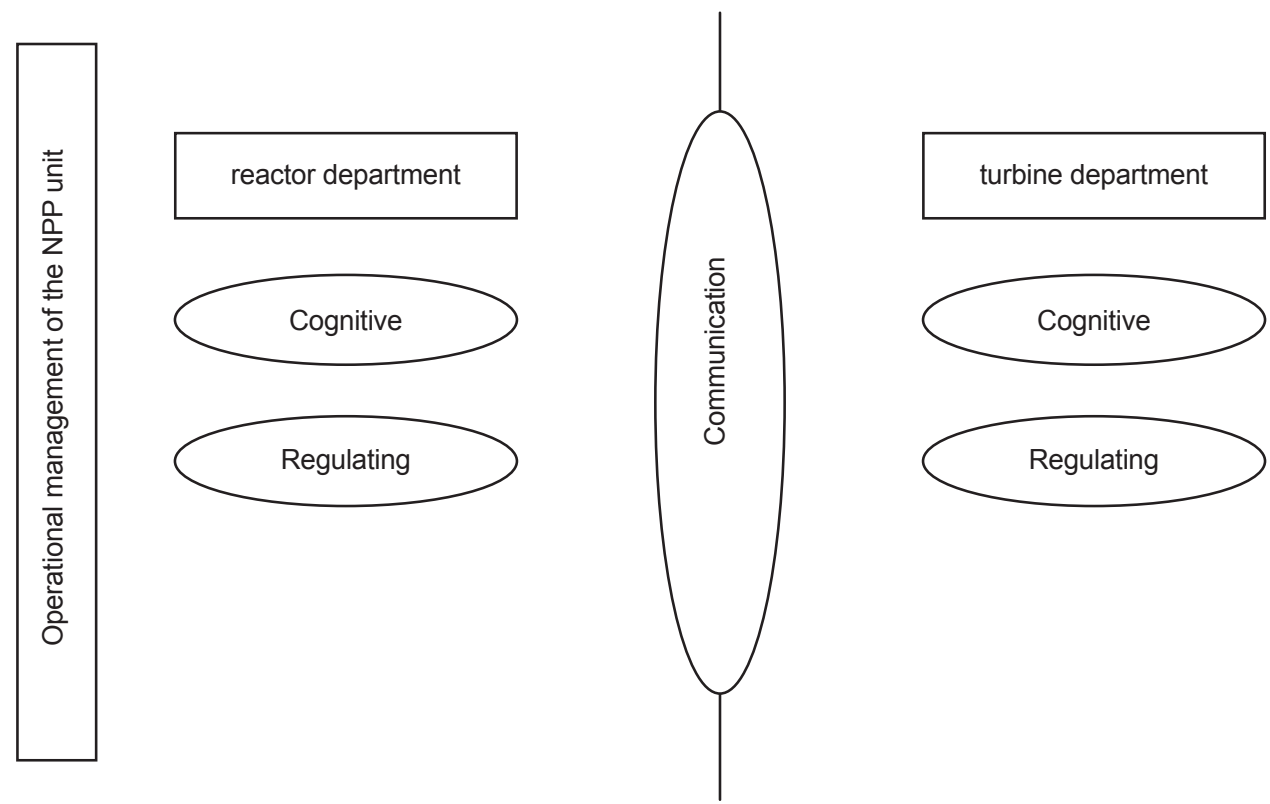

Technological process in the nuclear power plant unit

Figure 1. General structural scheme of SRO conceptual model 
obtained, which included 32 key characteristics of the power unit. Based on the analysis of the resulting semantic space, a general structural scheme of the SRO conceptual model was drawn up (see Figure 1).

Along the horizontal axis are the power unit operation links (cognitive component) and unit control links (regulatory component). The reactor department operation and control links are followed by those of the turbine department. This sequence reflects the main technological process control in the power unit: reactor-assisted coolant production (using water heated to a certain temperature), and coolant transformation into steam energy and then into electric power in the turbine generator. For this reason, the horizontal axis of the semantic space is interpreted as the "Technological process in the nuclear power plant unit" factor. Along the vertical axis, there are the links between the duty shift operators (communicative component), reflecting the SRO's views of the duty shift operators' interactions. Placed in the lower part of the vertical axis are the links between the characteristics reflecting the executive operators' jobs and duties; in the upper part are the links between the characteristics reflecting the supervisory duty shift operators' jobs and duties. The vertical axis is interpreted as the "Operational management of the NPP unit" factor. This general scheme suggests that the main technological process in the power unit and its control by the duty shift operators are presented in the SROs' conceptual model as relatively independent processes.

On the basis of the K-means clustering analysis, we came to a conclusion about the existence of two types of the power unit conceptual models, whereby both types retain the same general scheme (see Figure 2). The criteria for distinguishing these types were the relative number of strong and weak intra- and intersystem links, as well as the links between the operators. As Figure 3 shows, the relative number of strong (6-7 points) links of each kind in Type 1 conceptual models is significantly $(1.9 \div 2.1)$ larger than in Type 2 ( $p \leq 0,01 ; F$-criterion). On the contrary, the relative number of weak (1-2 points) links of each kind in Type 1 conceptual models is considerably smaller than in Type 2 ( $p \leq 0,01 ; F$-criterion).

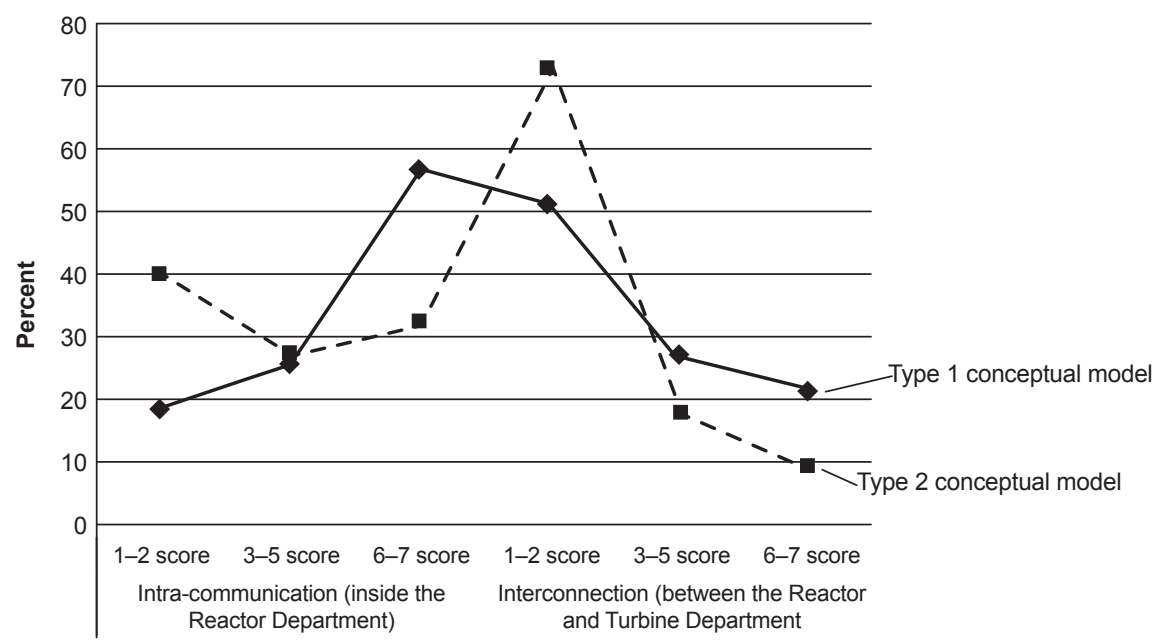

Figure 2. Two types of SRO conceptual models 
The distinction of these two types of conceptual models by this criterion was confirmed by the summarized data on distribution of links of different subjective strength (see Table 3 ). The relative number of strong (6-7 points) links between the key characteristics of the power unit in Type 1 conceptual models was 3.2 times larger, $41.0 \%$, as against $13.0 \%$ in Type 2 ( $\mathrm{p}<0.01$; chi-squared test).

Table 3. Distribution (\%) of links of different subjective strength depending on the conceptual model type

\begin{tabular}{|c|c|c|c|c|}
\hline \multirow{2}{*}{$\begin{array}{l}\text { Conceptual } \\
\text { model type }\end{array}$} & \multicolumn{3}{|c|}{ Subjective strength of links } & \multirow{2}{*}{$\begin{array}{c}\text { Total } \\
(\%)\end{array}$} \\
\hline & Weak & Average & Strong & \\
\hline Type 1 & 12.0 & 47.0 & 41.0 & 100.0 \\
\hline Type 2 & 29.0 & 58.0 & 13.0 & 100.0 \\
\hline
\end{tabular}

To illustrate this point, individual semantic spaces for each of the two conceptual model types are presented in Figures 3 and 4. These semantic spaces demonstrate the structural specifics of both conceptual model types. The subjective strength of links between the key characteristics is expressed in the distance between them: the stronger the link, the closer the key characteristics.

Figure 3 shows an individual semantic space of the Type 1 power unit conceptual model. Five subgroups include the key characteristics of the reactor and

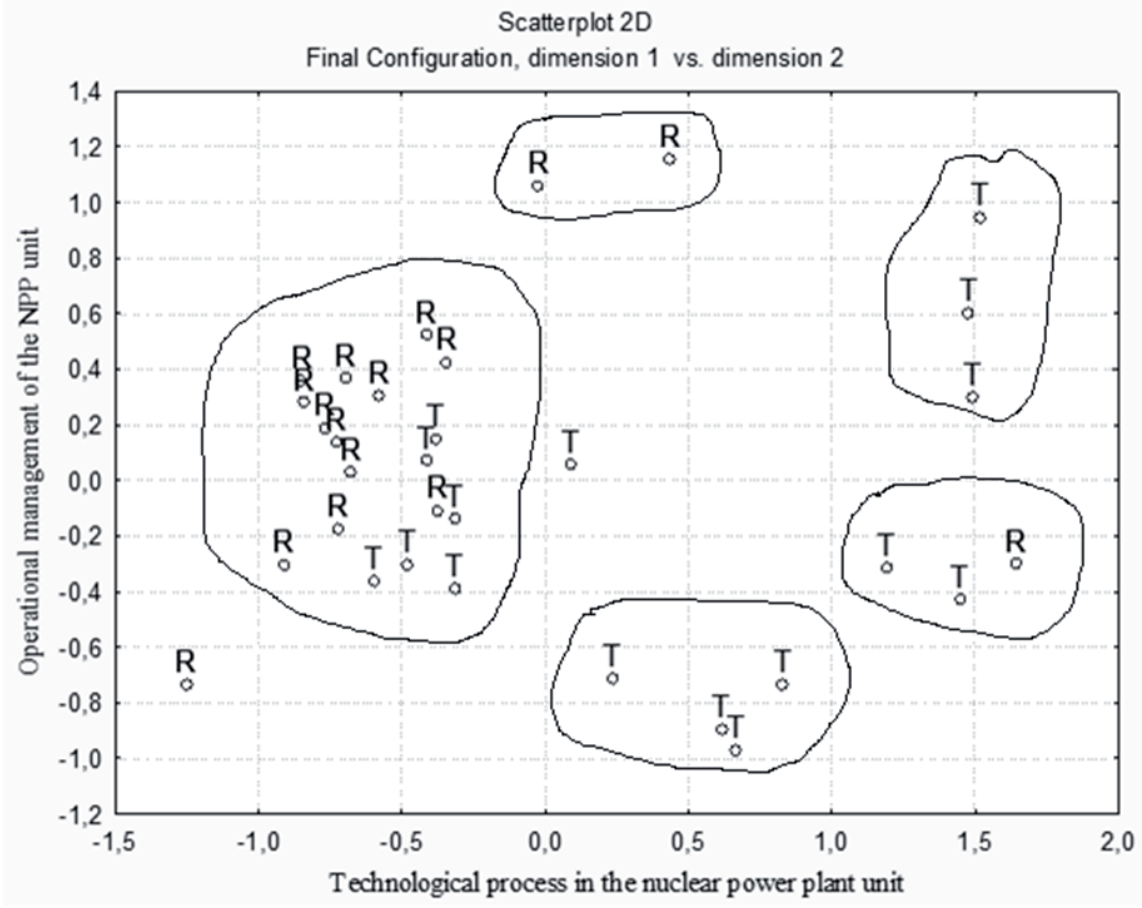

Figure 3. Individual semantic space of an SRO with Type 1 conceptual model $(\mathrm{R}, \mathrm{T}=$ key characteristics of the reactor and turbine departments, respectively) 


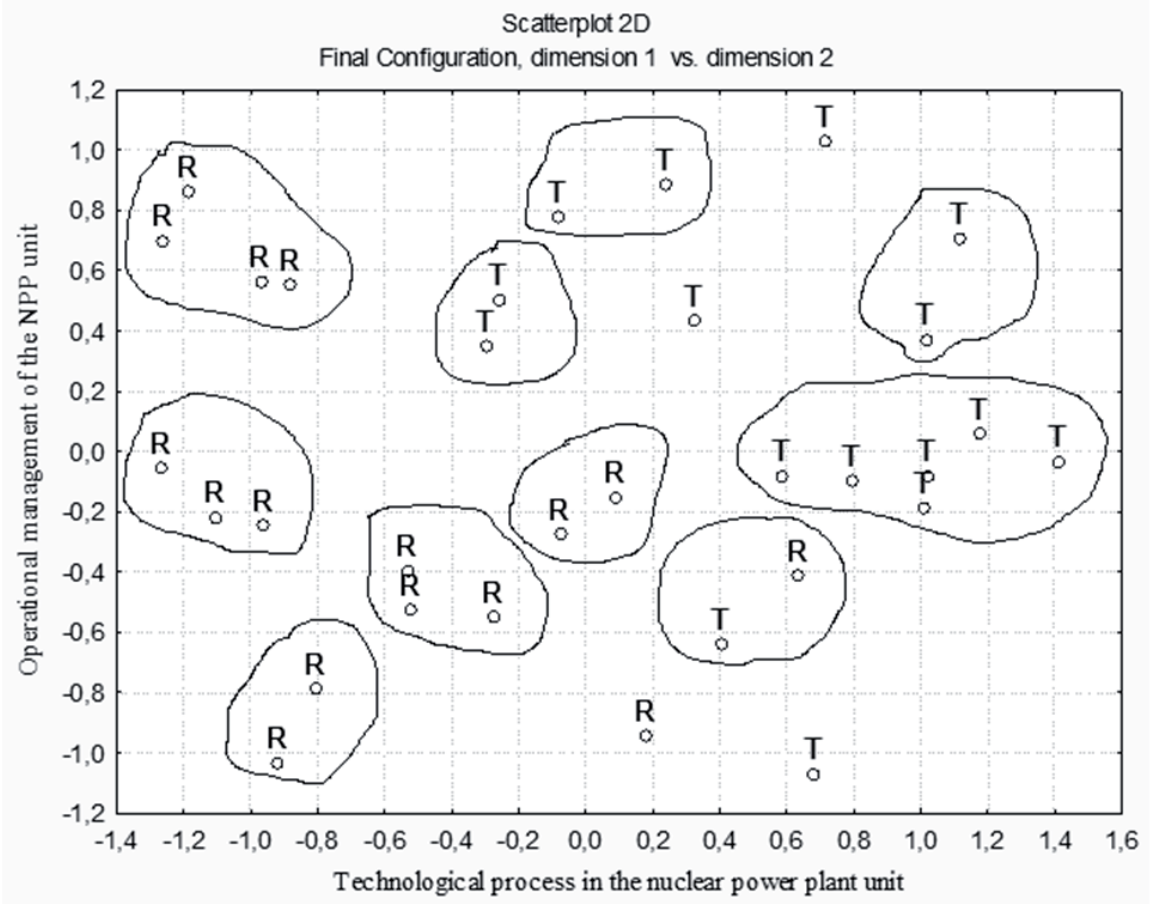

Figure 4. Individual semantic space of an SRO with Type 2 conceptual model (Nomenclatures are the same as in Fig. 3)

turbine departments (these subgroups were defined according to the clustering analysis, Ward's method, and city-block distance). The largest subgroup (Figure 3, left) contains 18 key characteristics, including 12 characteristics of the reactor department and 6 characteristics of the turbine department. Inclusion of these characteristics into one subgroup meant that the senior reactor operator considered the links between them strong. By their nature, these links were both intra- and intersystem ones. This conceptual model allowed the senior reactor operator to create a holistic and predictable representation of the operation of not only the reactor department for which he was responsible, but of the entire power unit, and to make independent decisions in regular and abnormal situations. No wonder that this SRO had the highest rate of professional efficiency of all the 64 participants.

Figure 4 shows an SRO individual semantic space with a Type 2 power unit conceptual model. In this model, 10 subgroups of key characteristics were identified, i.e., twice that of the previous case. As a rule, the subgroups contained 2-3 key characteristics only of the reactor or the turbine departments. Only two subgroups included the key characteristics of both departments. That is, in this conceptual model, strong intrasystem links dominated, while a small number of strong intersystem links prevented the creation of a holistic and predictable representation of the power unit operation. As a result, this SRO often was unable to make independent decisions and had the lowest rate of professional efficiency of all the 64 participants. 


\section{Discussion}

Here we address the main question of this study, namely the relationship between the structure of a conceptual model and the operator's profession efficiency. According to the results of professional efficiency scaling, the SROs were distinguished as having high, average, or low efficiency. A qualitative criterion for distinguishing the professional efficiency levels was the operators' ability to perform job duties in regular as well as in hazardous situations. Thus, the SROs with high professional efficiency included those who were able to independently perform their duties under both regular and abnormal conditions; those with average professional efficiency could independently perform their duties in regular situations, but in emergencies a supervisor should monitor their work; and those with low professional efficiency made mistakes in regular situations and needed significant additional training to improve their qualification (this category of persons is not recommended for the operator profile positions).

The results of the study show a clear relationship between the conceptual model types and SRO professional efficiency. The estimations made by the group of three experts were highly consistent: the values of Kendall's coefficient of concordance (W) were in the range of $0.79-0.87$. The evidence for a relationship between the conceptual model types and SRO professional efficiency was twofold. First, differences were revealed in the conceptual model types of senior reactor operators with high and average professional efficiency. The operators with high professional efficiency had predominantly Type 1 conceptual models with an average of 8 subgroups of key characteristics, while those with average professional efficiency had Type 2 conceptual models averaging 12 subgroups of key characteristics. It can be assumed that the operators with high professional efficiency, due to the larger number of highly interrelated key characteristics contained in the conceptual models, create a more holistic representation of the power unit operation.

The second type of evidence demonstrating the relationship between the conceptual model types and SRO professional efficiency was the positive correlation found between the level of professional competency and the number of strong intersystem links (Spearman's rho $=0.24 ; p<0.05$ ). This means that with an increase in the number of strong intersystem links, in transition from conceptual models of Type 2 to those of Type 1, the SRO's professional efficiency increased. This correlation between professional efficiency and the number of strong intersystem links, together with the absence of such a correlation for intrasystem links, point to a special role of strong intersystem links for the SROs to envisage the power unit operation as a whole, supporting their ability to make independent decisions.

\section{Conclusion}

The SRO conceptual models contain representations about the links between the key characteristics of the power unit that differ in their functions, connections, and subjective strength. This latter parameter indicates the predictable mutual influences of these characteristics: the stronger the links, the more predictable these interactions. For the operators, the most predictable were the links reflecting their interaction, and the least predictable were the power unit operation links 
between its technical subsystems and parameters. A general structural scheme of the key characteristics of the power unit can be explicated and presented as a two-dimensional semantic space, where the power unit operation and control links are along the horizontal axis, and the links between the duty shift operators are along the vertical axis. Two types of the power unit conceptual model were distinguished according to the relative number of strong intra- and intersystem links between the key characteristics of the power unit. In Type 1 conceptual models, this number is definitely larger than in Type 2 conceptual models. For the operators with Type 1 conceptual models, the power unit operation was more predictable than for those with Type 2 models. Strong intersystem links played the most important part in creating more predictable representations. A positive, although relatively low, correlation was found between the number of strong intersystem links in conceptual models and SRO professional efficiency indicators. We speculate that this accounts for their ability to make independent decisions in risky situations.

The revealed links between the SRO conceptual model types and professional efficiency and personality traits suggest the following areas where the obtained results may be applied:

- selection of operators and evaluation of their psychological readiness to independently manage HMS in regular situations and in emergencies;

- development of intelligent support systems for forming the operators' conceptual models required to manage HMS.

The results of an earlier study (Oboznov et al., 2013b) demonstrated the practical feasibility of this latter task.

\section{Acknowledgements}

The study was supported by the Russian Humanitarian Science Foundation, grants 08-06-00403a and 11-06-01136a.

\section{References}

Anderson, J. (2002).Cognitivnaya psikhologiya [Cognitive psychology]. Saint Petersburg, Russia: Piter.

Anokhin, A.N., \& Ostreykovsky, V.A. (2001). Voprosy ergonomiki v yadernoy energetike [Ergonomic issues in the nuclear industry]. Moscow: Energoatomizdat.

Bessonova, Yu.V. (2012). Typologiya mentalnykh reprezentatsiy professionalnykh zadach u spetsialistov atomnoy energetiki [Typology of job task mental representations for nuclear reactor operators]. Eksperimentalnaya psihologiya [Experimental Psychology], 5(2), 102-118.

Chernetskaya, E.D. (2014). Tipy kontseptualnykh modeley u operatorov atomnykh stantsiy [Conceptual model types of nuclear power plant operators]. In A.N. Anokhin, P.I. Paderno, \& S.F. Sergeyev (Eds.), Trudy Mezhdunarodnoy nauchno-prakticheskoy konferentsii "Psikhologiya truda, inzhenernaya psichologiya i ergonomika, 2014 (Ergo-2014)" [Proceedings of the international conference "Psychology of labor, engineering psychology and ergonomics, Ergo-2014”] (pp. 194-201). Saint Petersburg, July 3-5, 2014. Saint Petersburg, Russia: Mezhregionalnaya ergonomicheskay assotsiatsiya. 
Cooke, N.M., \& McDonald, J.E. (1987).The application of psychological scaling techniques to knowledge elicitation for knowledge-based systems. International Journal of Man-Machine Studies, 26, 533-550. doi: 10.1016/S0020-7373(87)80086-X

Galaktionov, A.I. (1992). Sistemnoe issledovanie psychicheskikh obrazov, formiruemykh operatorom-tekhnologom [System research of operators' mental images]. In V.A. Bodrov \& V.F. Venda (Eds.), Sistemnyy podkhod v inzhenernoy psikhologii i psikhologii truda [Systemic approach to engineering psychology and psychology of labor]. (pp. 92-105). Moscow: Nauka.

Golikov, Yu.Ya. (2003). Metodologiya psihologicheskikh problem proektirovaniya tekhniki [Methodology of psychology in engineering design]. Moscow: PER SE.

Golikov, Yu.Ya., \& Kostin, A.N. (1999). Teoriya i metody analiza problemnostey v slozhnoy operatorskoy deyatelnosti [Theory and method for problem analysis of complex action]. In Problemnost $v$ professionalnoy deyatelnosti [Issues in professional activity]. Moscow: Institute of Psychology RAS.

Lomov, B.F. (1977). O putyakh postroyeniya teorii inzhenernoy psikhologii na osnove sistemnogo podkhoda [Ways to construct a theory of engineering psychology on the basis of a systematic approach]. In Inzhenernaya psikhologiya. Teoriya, metodologiya, prakticheskoye primeneniye [Engineering psychology. Theory, methodology and application]. (pp. 31-55). Moscow: Nauka.

Munipov, V.M., \& Zinchenko, V.P. (2001). Ergonomika: cheloveko-orientirovannoe proektirovanie tekhniki, programmnykh sredstv i sredy [Ergonomics: Human-oriented design for equipment, software and working environment]. Moscow: Logos.

Oboznov, A.A. (2009). Struktura konceptualnoy modeli u cheloveka-operatora: sistemnyy podkhod [The conceptual model structure of the human operator: A systemic approach]. In V.A. Bodrov \& A.L. Guravlev (Eds.), Aktualnye problemy psikhologii truda, inzhenernoy psikhologii i ergonomiki [Topical issues in psychology of labor, engineering psychology and ergonomics]. (Vol. 1, pp. 403-413). Moscow: Institute of Psychology RAS.

Oboznov, A.A., Chernetskaya, E.D., \& Bessonova, Yu.V. (2013a). Kontseptualnye modeli atomnoy stantsii u operatorov s raznym professionalnym stazhem [Conceptual models of nuclear power plant operators with various amounts of professional experience]. Psychologicheskiy zhurnal [Psychological Journal], 4(34), 47-57.

Oboznov, A.A., Dozortsev, V.M., Nazin, V.A., \& Gutsykova, S.V. (2013b). Intellektualnaya systema formirovaniya u operatorov mentalnykh reprezentatsiy tekhnologicheskogo obyekta [An intelligent system for constructing mental images of technological infrastructure]. Rossiyskiy nauchnyy zhurnal [Russian Scientific Journal], 7(38), 133-138.

Oshanin, D.A. (1969). Rol operativnogo obraza v vyyavlenii informatsionnogo soderzhaniya signalov [The role of operative images in revealing the information content of signals]. Voprosy psikhologii [Issues in Psychology], 4, 24-34.

Oshanin, D.A. (1977) Kontseptsiya operativnosti otrazheniya v obshey i inzhenernoy psikhologii [The concept of the operativeness of reflection in general and engineering psychology]. In Inzhenernaya psikhologiya: Teoriya, metodologiya, prakticheskoe primenenie [Engineering psychology. Theory, methodology and application]. (pp. 134-149). Moscow: Nauka.

Ryabov, V.B. (2014). Kontseptualnye modeli i ikh ispolzovaniye v prikladnykh inzhenerno-psikhologicheskikh i ergonomicheskikh issledovaniyakh [Conceptual models and their use in applied psychological and ergonomic research]. In A.A. Oboznov, A.L. \& Zhuravlev (Eds.), Aktualnye problem psikhologii truda, inzhenernoy psihologii i ergonomiki [Topical issues in psychology of labor, engineering psychology and ergonomics]. (Vol. 6, pp. 285-298). Moscow: Institute of Psychology RAS. 
Velichkovsky, B.M. (2006). Cognitivnaya nauka: Osnovy psikhologii poznaniya [Cognitive science: Foundations of epistemic psychology]. Vol. 2. Moscow: Smysl/Academia.

Vygotsky, L.S. (1982) O psychologicheskikh sistemakh. In: A.R. Luria \& M.G. Yarochevsky (Eds.) Vygotsky L.S. Sobranie sochineniy $v 6$ tomakh.Vol.1. Voprosy teorii i istorii psihologii [Collected works in 6 volumes. Vol. 1. Theory and history of psychology] (pp. 109-131). Moscow: Pedagogika.

Welford, A.T. (1961). On the human demands of automation: Mental work conceptual model, satisfaction and training. Industrial and Business Psychology, 5, 182-193.

Zinchenko, V.P. (1970). Analiz deyatelnosti operatora [Analysis of the operator's action]. In Ergonomika: printsipy i rekomendatsii [Ergonomics: Principles and recommendations]. Vol. 1. Moscow: VNIITE. 